\title{
RESEARCHING ELEMENTS OF CROSS-BORDER SOCIAL COHESION: THE CASE OF SLOVENE BORDER AREAS
}

\author{
Milan Bufon ${ }^{1}$
}

Received 26 November 2012; Accepted 12 April 2013

\begin{abstract}
The article discusses the possibility of "measuring" the intensity of cross-border cohesion and co-dependence on the case of Slovene border areas. It presents first an overview of how geography has studied and interpreted borders, and what an impact had borders on both space and society. The author then analyses both qualitative and quantitative structure of border areas prior to Slovenia's admission to the Schengen Space and explores recent changes after 2007, when border controls on the major part of his borders where eliminated. These developments produced several spatial and social (re)integration trends that have been detected in the author's analyses through some comparable research methods and indicators, permitting also to rank Slovenian border sections and individual sub-areas by the intensity and quality of their cross-border cohesion.
\end{abstract}

Key words: Border areas, cross-border cohesion, Slovenia

Povzetek: Članek obravnava možnost »merjenja» intenzivnosti čezmejne kohezije oziroma soodvisnosti na primeru slovenskih obmejnih območij. Najprej prikazuje, kako je geografija proučevala in interpretirala meje ter njihov vpliv na obmejno družbo in prostor. Avtor nato analizira tako kvalitativne kot kvantitativne vidike slovenskih obmejnih sektorjev pred vstopom Slovenije $v$ t.i. schengenski prostor in obravnava novejše spremembe $v$ strukturi čezmejnih vezi po letu 2007, ko so bile mejne kontrole $v$ večini teh mejnih sektorjev odpravljene. Spremembe so privedle do različnih družbenih in prostorskih (re)integracijskih teženj, ki jih je avtor poskusil določiti na podlagi nekaterih komparativnih raziskovalnih metod in kazalcev. Slednji so tudi omogočili rangiranje slovenskih mejnih sektorjev in njihovih podenot po stopnji in dejavnikih čezmejne kohezije.

\section{Introduction}

Borders have always been a subject of intense geographical research as they divide different homogenous or functionally co-dependent areas (regions) on the one hand and different administrative and political units defined by joint administration, "property" and social

\footnotetext{
${ }^{1}$ Prof. Milan Bufon, Ph.D., Head, Institute for Geographical Studies, Science and Research Centre, University of Primorska, Koper, Titov trg 5; e-mail: milan.bufon@zrs.upr.si
} 
identification or affiliation (territories) on the other. Spatial "demarcation" thus "decomposes" a common geographical area into individual units according to a variety of criteria mostly related to natural, cultural and social spheres (Bufon, 1996). Taking into account both the elements of functionality and homogeneity, the process of spatial differentiation evolves in accordance with either inductive (bottom-up) or deductive (top-down) logic. As a result, an "open" geographical area can witness simultaneous "formation" of very different "self-contained" units, which can "co-exist" at different levels of social life and are subject to constant change in time.

This fact makes both geographical and social areas highly relative in nature and leads one to the conclusion that individuals and social groups can "interpret" and "understand" it in a variety of manners (Bufon, 2010). Social groups establish not only "real" political, administrative and spatial planning units or borders, but also "imagined" cultural and social boundaries based on the perception and construction of different cultural and social environments formed on the basis of existing lifestyles and customs, historical circumstances, etc. Geography addresses such topics within a variety of sub-disciplines and geographical "schools": until recently, the Slovene area has modelled itself upon German social geography (Maier et al., 1977), which developed a special research method for determining and comparing the occurrence of the socalled "spatially relevant social activities" in a certain area, such as life in a community, work, shopping, education, spare time, etc. Having studied their occurrence in geographical space, researchers concluded that it is possible to determine certain shared customs that not only differentiate one social group from another, but also form special "areas of action". Such environments can assume characteristics of potential spatial planning areas or even potential territories, thus "demarcating" individual or particular social areas. Similar conclusions have been reached by the Anglo-American behavioral geography (Segall et al., 1966; Sonnenfeld, 1976), which by contrast to social geography lays greater emphasis on more individual views of space, its perception and interpretation. Recently, one could place in this context the so-called "postmodern" cultural geography and its understanding and exploration of questions related to the "border condition" in today's increasingly globalized and "borderless" world (Paasi, 2009).

The most intense research into characteristics and impacts of "borders" on space and society has been traditionally conducted by political and economic geography. The latter mostly regards borders as barriers to spatial dissemination of innovations - an aspect that has been emphasized by social studies on information flow. When studying the border between the USA and Mexico, Reynolds and McNulty realized that people living along it, yet far from border posts, found it much more difficult to include cross-border areas into their action areas than people living in their vicinity (Reynolds and McNulty, 1971). However, system theory argues that social areas are relatively open systems in which the function of borders is to "filter" external influences. As a result, the level of cross-border cohesion depends on the level of physical porousness of the border on the one hand and on dynamism and vitality of societies on the both sides of the border on the other (Strassoldo, 1973). In the 1970s and the 1980s, a time marked by growing international integration, the German and French areas (Bufon, 2006a) witnessed a great number of empirical studies trying to determine the factors facilitating or impeding crossborder cooperation. According to their results, ranking among the former were a highly developed system of industrial society in border areas, a joint information system, the knowledge of language spoken in the neighbouring country and a positive attitude to one's neighbours and cross-border cooperation, while ranking among the latter were lack of crossborder transport and information connections, uncoordinated planning in border areas and the adaptation of population to the closed border. The same time also saw the first attempts to determine the spatial reach of cross-border ties and to define border areas as that part of the borderland that is affected by both positive and negative impacts of the border itself and cross-border ties.

For the purpose of this article, the term "cross-border region" denotes a system of border areas connected by the same social and cultural affinities and/or social and economic co-dependence (Bufon, 1993 and 2001a). In many cases, both factors spring from the "youthfulness" of political and geographical transformations and, in accordance with the principle of spatial persistence, aspire to preserve traditionally unified cultural, historical or functional social areas. On the basis of such observations, we proposed the hypothesis that those border areas which have recently 
witnessed the most serious troubles owing to the introduction of a political border, have at the same time the highest potential for cross-border (re)integration. As for the delimitation of border areas, one has to take into account that, in terms of institutional setting, European bilateral agreements usually stipulate special regimes for cross-border social and economic cooperation, valid within an area not exceeding the distance of $25 \mathrm{~km}$ from the border line. In addition to this institutionally determined range, there also exist a range that is a result of functional, cultural and historical criteria and that gives rise to border areas characterized by different levels and types of the intensity of cross-border communication (Bufon, 1998).

In view of the above-mentioned, it is clear that contemporary political geography is no longer interested only in the study of political borders, their formation, line and transformation, but also in characteristics and structure of border areas, their regional differences and similarities, the impact of political factors on the development of spatial and social organization of the population along the border, directions of its spatial mobility, its evaluation and perception of one's own and the neighbouring environments, and last but not least, the relation between national centres vs. border areas, impacts of international integration on the developmental potential of border areas, and strengthening of functional and institutional cross-border ties (Prescott, 1987). The interest of political geography has thus turned from traditional research into "conflict" border situations to the study of "harmony" in border landscapes (Rumley and Minghi, 1991). In his well-known model of cross-border cohesion, House argued that spatial and social ties resulted not only from the cohesion between border areas and regional and national centres within one state, but also from the cohesion between the above-mentioned spatial levels of one state and those of the neighbouring state (House, 1981). He placed special emphasis on the importance of local cross-border ties between two border areas: they were weaker when the two states were in conflict or fostered a centralized national system of government, and formed the major part of cross-border cohesion in the case of "normal" international and national political situations.

Even if the "borderless" Schengen area has not witnessed complete liberalization of border regimes and total abolition of border barriers, at least not from the point of view of administration and planning, one can nevertheless notice that cross-border regions have started to function in accordance with normal functional and gravitational principles. That is particularly noticeable in the case of not only urban border areas characterized by functional co-dependence, but also historical multicultural regions characterized by a shared cultural and spatial identity. Not surprisingly, such border areas witness an increasing need for appropriate "facilitation" and "management" of cross-border cooperation as it is in such areas that today's process of European social and spatial (re)integration is being realized in the most tangible manner (Bufon, 2006b and 2011). Such developments naturally call for a more precise determination of those instruments that would help researchers and planners to "measure" the intensity of cross-border social and spatial ties and, consequently, the efficiency and success of the adopted policies of cross-border cooperation.

\section{The structure of border areas and the intensity of cross-border cohesion in Slovene border sections prior to Slovenia's admission to the Schengen Area}

Our past research has highlighted that Slovenia is one of the most typical and interesting border or "contact" social areas in Europe and a real "laboratory" for research into the transformation of function of borders in Europe (Bufon, 2002). In Slovenia, the borderline accounts for almost $6 \mathrm{~km} / 100 \mathrm{~km}^{2}$ of surface. As a result, the country ranks second in terms of "mathematical" border territory, with only Luxemburg preceding it. Similar results are obtained if one calculates the percentage of the country's territory composed of border areas: if one takes a 25-km zone for the criterion, then one realizes that such zones account for more than $75 \%$ of the entire surface area; if one takes the administrative structure for the criterion and takes into account the percentage of municipalities whose distance from the state border does not exceed $25 \mathrm{~km}$, one finds out that more than $60 \%$ of Slovene municipalities meet such a criterion. The very heart of Slovenia with Ljubljana as its capital city is just an hour's drive (to be more precise, 
from 60 to $110 \mathrm{~km}$ away) from the majority of the state borders; it is only to reach the border with Hungary that one needs a double amount of time (the distance being around $220 \mathrm{~km}$ ).

For Slovenia, a high percentage of border territory has always been an advantage rather than a disadvantage as it was via the borders with Italy and Austria that former socialist Yugoslavia fostered fairly strong economic ties with developed European areas. In addition, the border areas in the two neighbouring countries have been home to the Slovene minority, which helped increasing the intensity of social and cultural cross-border ties at local level. Only the border area with Hungary witnessed a less favourable situation as the border functioned as the "Iron Curtain", hindering cross-border communication. The disintegration of Yugoslavia and the establishment of independent states of Slovenia and Croatia in 1991 gave rise to a new situation: the former Slovene-Croatian republican border first gained the status and function of a state border and later of a European "external" border, which fairly impeded previously fluent cross-border communication (another reason being the never-ending border dispute between Slovenia and Croatia). By contrast, Slovenia's admission to the EU and to the Schengen Area in 2004 and 2007 respectively considerably changed the function of its previously "external" borders, which resulted in total abolition of border checks.

An undoubtedly important indicator of cross-border cohesion is cross-border traffic or, more precisely, the number of cross-border passengers. As mentioned above, prior to 1991 west- and northbound destinations witnessed relatively heavy cross-border traffic. Between 1992 and 1995, all Slovene borders saw a considerable increase in traffic of passengers (from around 143 to around 180 millions) even if the period was marked by the war in former Yugoslavia, which almost brought transit traffic to a standstill. The number of border crossings (that is the number of exits from the country and entries into it) rose from around 51 million to around 75 million along the Slovene-Italian border, from around 39 million to around 51 million along the Slovene-Austrian border, and from around 2 million to around 5 million along the SloveneHungarian border, whereas cross-border traffic along the Slovene-Croatian border was unchanged, with the number of crossings amounting to around 50 million. As far as total border crossings after that year are concerned, no major changes have been observed: traffic of passengers has stayed at the same high level, which means that Slovene borders are daily crossed by an average of almost half a million people. With $30 \%$ of total crossings being done by Slovene citizens, Slovene borders are daily crossed by around 140,000 Slovene citizens, which accounts for $7 \%$ of Slovenia's population. To put it differently, each Slovene citizen visits a neighbouring country on average every fortnight.

By 2002, the only changes witnessed had been related to the internal distribution of crossings since the number of crossings went down along the border with Italy (to around 65 millions) and Hungary (to around 4 million), with the reason most probably being the weakening of functional, particularly economic motives for a cross-border trip, while the number of crossings went up along the border with Croatia (exceeding 60 million), where cross-border ties were normalized and strengthened. Such a structure had not really changed by 2007 when the Slovene Statistical Office stopped recording the number of crossings along its "internal" European borders.

\begin{tabular}{|l|c|c|c|c|c|c|}
\hline & 1992 & 1995 & 2002 & 1992 & 1995 & 2002 \\
\hline & \multicolumn{7}{|c|}{ Million passengers } & \multicolumn{3}{c|}{$[\%]$} & 36.3 \\
\hline SLO/I & 51.4 & 74.5 & 64.9 & 36.0 & 41.3 & 27.1 \\
\hline SLO/A & 39.4 & 50.7 & 48.6 & 27.6 & 28.1 & 2.3 \\
\hline SLO/H & 1.9 & 4.8 & 4.1 & 1.3 & 2.7 & 34.3 \\
\hline SLO/CRO & 50.2 & 50.3 & 61.3 & 35.1 & 27.9 & 100.0 \\
\hline Total & 142.9 & 180.3 & 178.9 & 100.0 & 100.0 & \\
\hline
\end{tabular}

Tab 1. Slovenia - structure of border crossings per border section, 1992 - 2002.

Source: Statistical Office of the Republic of Slovenia.

In order to determine the basic characteristics of Slovene border sections more precisely, the following indicators were used:

- $\quad$ the percentage of total land border length, 
- the percentage of border posts,

- $\quad$ the number of border posts per $100 \mathrm{~km}$ of border,

- $\quad$ the percentage of total cross-border traffic by taking into account the mean value over a timespan of several years.

The ratio between the land border length and the percentage of cross-border traffic indicates higher or lower traffic intensity in relation to the expected mean value. Even if accounting for only $17 \%$ of total land border length, the border section with Italy recorded $38 \%$ of total crossborder traffic. In the case of the border section with Austria, cross-border traffic proved to be in accordance with our expectations (28\% of total land border length and the same percentage of cross-border traffic), whereas cross-border traffic along the border sections with Hungary (around $8 \%$ of total land border length and $2 \%$ of cross-border traffic) and Croatia ( $47 \%$ of total land border length and $32 \%$ of cross-border traffic) was lower than expected.

The ratio between total land border length and the presence of border infrastructure reveals a slightly different picture: the border section with Italy was more than two times more "porous" than the expected mean value (17\% of total land border and as many as $39 \%$ of all border posts); the ratios of border porousness of the border sections with Austria and Hungary were more or less the same, revealing a "normal" physical porousness of the border, whereas the porousness of the border section with Croatia remains deficient $(29 \%$ of border posts along $47 \%$ of total land border length). Such a state of affairs is corroborated by the "absolute" indicator related to the average number of border posts per $100 \mathrm{~km}$ of borderline, amounting to around 8 ( 1 border post per $12.5 \mathrm{~km}$ of borderline) in the case of Slovenia. Along the border sections with Austria and Hungary, it reached the value around 7 , along that with Croatia to around 5 ( 1 border post per $20 \mathrm{~km}$ of borderline), and along that with Italy to more than 17 ( 1 border post per less than $6 \mathrm{~km}$ of borderline).

The overview of the basic structure of Slovene border sections and their cross-border flows, derived from available statistical data and complemented by a socio-economic analysis of the structure of border municipalities on the both sides of the border and their similarities and differences, definitely has to be complemented by fieldwork and surveys conducted among border populations, especially for the purpose of studies of the actual intensity of cross-border ties. Our research paid special attention to the state of affairs in the cross-border region of Gorizia and partly also that of Istria, which appeared to be the areas with the highest level of cross-border cohesion in Slovenia (Bufon, 1995 and 2001b). On the basis of the results of the survey conducted among people living on both sides of the border, we established not only how local population perceived their own and the neigbouring border areas, but also the direction, the intensity and partly also the frequency of cross-border ties, with special emphasis on the motivations for cross-border visits.

\begin{tabular}{|l|c|c|c|c|}
\hline & 1 & 2 & 3 & 4 \\
\hline SLO/I & 17.4 & 38.5 & 17.3 & 38.0 \\
\hline SLO/A & 27.9 & 26.3 & 7.4 & 27.6 \\
\hline SLO/H & 7.6 & 6.6. & 6.8 & 2.2 \\
\hline SLO/CRO & 47.1 & 28.6 & 4.8 & 32.2 \\
\hline Total & 100.0 & 100.0 & 7.8 & 100.0 \\
\hline
\end{tabular}

Tab 2. Selected characteristics of the border sections of the Republic of Slovenia.

1 - Percentage of total border length per border section

2 - Percentage of border posts per border section

3 - Number of border posts per $100 \mathrm{~km}$

5 - Percentage of total cross-border traffic per border section

Source: Statistical Office of the Republic of Slovenia. 
By using an integral approach to the study of cross-border areas, we were able to carry out a typification of border areas and their sections according to the intensity of their cross-border cohesion and functional complementarity, as well as to verify the hypothesis that neighbouring (cross)-border areas are characterized by greater co-dependence than individual border sections and more distant areas within the same country. In order to obtain the level of crossborder cohesion, we first selected the key indicators (e.g.: the percentage of respondents who stated that they had relatives/friends on the other side of the border; the percentage of respondents who stated that they visited neighbouring places once a day or at least a few times per week; the percentage of respondents who stated that they regularly attended social events on the other side of the border; the percentage of respondents who stated that they understood/spoke the language of the neighbouring country; the percentage of respondents who stated that they were daily audience of the media of the neighbouring country) and then, on the basis of a quantitative standardized scale, determined similarities and differences between the indicators and total calculated values related to individual border areas and its sections.

Such a method allowed us to rank individual border areas according to a general estimated cross-border cohesion value, but also to determine which indicator proved to be the most important or influential. In addition, we used the same data to determine whether the values related to individual "pairs" of smaller border sections symmetrically located on both sides of the border exhibited a higher level of internal similarity than the one comparing individual smaller border sections and mean values of the entire border area in question on each side. In the case of Gorizia, the hypothesis was confirmed, whereas in the case of Istria, its border sections were characterized by higher discontinuity, in particular if one compared values related to the Slovene-Italian border area on the one hand and those related to the Slovene-Croatian border area on the other. The comparison between Gorizia and Istria also revealed that the latter recorded higher migratory mobility patterns of population, extending over the quite limited "space of cross-border action" as in the case of the Gorizia region. The former, instead, exhibited a higher level of social cohesion between the border populations, as well as higher intensity of functional cross-border ties.

\section{Towards a cross-border (re)integration: changes in values and attitudes after 2007}

A similar method was used in 2007 when we conducted a telephone survey in which all the Slovene border areas were included (Bufon, 2008). The survey included 250 respondents on each border section, equally distributed in the border municipalities, according to the number of inhabitants, demographic structure and given spatial distribution, permitting thus a statistical comparison not only between individual border sections and their structural elements, but also between smaller socially and spatially homogeneous units within these sections. Unfortunately, we did not manage to include the border population from the neighbouring countries and, consequently, limited the analysis of similarities and differences in the intensity of cross-border integration to the comparison between Slovene border areas and their sections. The results of the analysis, the aim of which was to examine the expectations of the border population as regards anticipated changes in the level of cross-border cohesion along different border sections prior Slovenia's admission to the Schengen Area, were used as a basis for the comparison with the results obtained by re-conducting the survey in 2010, two years after Slovenia joined the Schengen Area.

As for the impact of Slovenia's admission to the Schengen Area upon the development of crossborder ties, the majority of respondents living along the border with Italy fell into two groups: one believed that the ties were unchanged, the other that they improved (in both cases, such an opinion was held by around $42 \%$ of respondents). In comparison with the results of the 2007 survey, there was a small decrease in the number of those who perceived the event as an opportunity to improve cross-border ties (their percentage fell from $49 \%$ to around $43 \%$ ) and a considerable increase in the number of those who perceived it as a factor of deterioration in such relations (their percentage rose from around $4 \%$ to around $13 \%$ ). 


\begin{tabular}{|l|c|l|c|c|}
\hline $\mathbf{2 0 0 7}$ & I & A & H & CRO \\
\hline Improved & 49.0 & $\mathbf{4 8 . 4}$ & 43.0 & 14.3 \\
\hline Deteriorated & 4.4 & $\mathbf{3 . 9}$ & 1.6 & 52.4 \\
\hline Unchanged & 42.2 & $\mathbf{4 0 . 6}$ & 50.6 & 29.4 \\
\hline No response & 4.4 & $\mathbf{7 . 1}$ & 4.8 & 3.9 \\
\hline $\mathbf{2 0 1 0}$ & $\mathbf{I}$ & $\mathbf{A}$ & $\mathbf{H}$ & CRO \\
\hline Improved & $\mathbf{4 2 . 5}$ & $\mathbf{3 3 . 4}$ & 51.0 & 12.1 \\
\hline Deteriorated & 13.3 & $\mathbf{1 1 . 2}$ & 4.0 & 39.1 \\
\hline Unchanged & 42.4 & $\mathbf{5 0 . 2}$ & 43.8 & 45.8 \\
\hline No response & 1.8 & $\mathbf{5 . 3}$ & 1.2 & 3.0 \\
\hline
\end{tabular}

Tab 3. Perceived development of cross-border relations after Slovenia's admission to the Schengen Area as assessed in 2007 and 2010 (in \%).

An even greater difference was recorded in the answers of people living along the border with Austria where approximately a half of the respondents believed that after Slovenia's admission to the Schengen Area the cross-border ties were unchanged, whereas a third believed that they improved, and more than a tenth that they deteriorated. In comparison with the expectations fostered in 2007, the percentage of "positively" oriented respondents decreased from more than $48 \%$ to around $33 \%$, while the percentages of respondents holding "neutral" and "negative" viewpoints increased (from around $41 \%$ to around $50 \%$ and from around $4 \%$ to around $11 \%$ respectively). The most positive attitude towards the impact of Slovenia's admission to the Schengen Area upon the development of cross-border ties was fostered by people living along the border with Hungary where $51 \%$ of respondents believed that they improved, around $44 \%$ that they were unchanged, and $4 \%$ that they deteriorated. This was the only area that witnessed an increase in the "positive" stance in comparison with the expectations of 2007. Slightly more "optimistic" or, more precisely, less "pessimistic" views were held by the population living along the border with Croatia where in 2007 more than $52 \%$ of respondents believed that the ties would deteriorate, whereas in 2010 their percentage fell to around $39 \%$. Concomitantly, the percentage of respondents who saw no changes in the development of cross-border relations after 2007 considerably increased (from around 29\% to around 46\%).

Being aware that one can get fairly approximate answers when it comes to the general assessment of changes in cross-border ties, we tried to obtain more revealing views of the impact of Slovenia's admission to the Schengen Area upon the following selected elements of cross-border cohesion: attendance at cultural and sporting events held on the other side of the border, fostering of personal cross-border contacts, work possibilities, study opportunities, shopping, real estate purchase and cross-border cooperation between municipalities. According to respondents living along the border with Italy, the free cross-border circulation had a major impact mostly on study opportunities (57\%), cooperation between local administrations (52\%), cross-border work $(51 \%)$, real estate purchase (49\%), shopping $(48 \%)$ and fostering of personal contacts $(43 \%)$. Respondents living along the border with Austria believed that the abolition of border posts had a major impact on cross-border shopping (53\%), study opportunities (50\%), work (48\%) and cooperation between border municipalities (46\%). Respondents living along the border with Hungary perceived the greatest positive changes in cross-border cooperation between municipalities (62\%) followed by the fostering of cross-border contacts $(43 \%)$, crossborder shopping (41\%) and attendance at cultural and sporting events on the other side of the border (37\%). As expected, respondents living along the still controlled border with Croatia perceived no major positive impacts of Slovenia's admission to the Schengen Area on any of the fields proposed. Interestingly, they even believed that the event would have negative impacts upon cross-border employment and study opportunities (such an opinion was expressed by $54 \%$ of respondents). 


\begin{tabular}{|l|c|c|c|c|}
\hline & I & A & H & CRO \\
\hline Attendance at cultural events & 32.5 & 26.9 & 37.1 & 22.3 \\
\hline Attendance at sporting events & 33.4 & 35.0 & 37.0 & 24.7 \\
\hline Fostering of personal contacts & 42.9 & 28.6 & 42.9 & 28.0 \\
\hline Work possibilities & 50.9 & 48.4 & 17.0 & 26.5 \\
\hline Study opportunities & 57.1 & 50.2 & 301. & 22.3 \\
\hline Shopping & 47.5 & 52.7 & 40.6 & 26.3 \\
\hline Real estate purchase & 48.8 & 24.9 & 34.5 & 35.8 \\
\hline Cooperation between municipalities & 52.0 & 45.8 & 62.1 & 32.5 \\
\hline
\end{tabular}

Tab 4. Percentage of respondents believing that Slovenia's admission to the Schengen Area had a positive impact on the development of cross-border ties in the following field. Source: own results.

The survey conducted in 2010 also confirmed the high level of cultural cross-border affinity along the Slovene border areas. The neighbours' tongue was spoken and/or understood by as many as $90 \%$ of respondents living along the border with Italy, $85 \%$ of those living along the border with Austria, $57 \%$ of those living along the border with Hungary, and all respondents from the Slovene-Croatian border area, which paints almost the same picture as the one of 2007. Moreover, all border areas in question exhibited widespread belief that it was necessary to possess the knowledge of neighbouring languages (such an opinion was held by as many as $70-75 \%$ of respondents). The answers to the question whether it should be obligatory to possess such knowledge were slightly more varied, with the statement being supported by around $21 \%$ of respondents living along the border with Italy and only by $10-15 \%$ of respondents from other border areas.

Widespread knowledge of neighbours' languages enables the population of Slovene border regions to be a fairly regular audience of the media operating in neighbouring countries. Around $8 \%$ of respondents living along the border with Italy were regular listeners to Italian radio programmes, around $41 \%$ were regular watchers of Italian TV programmes, and around $10 \%$ were regular buyers of Italian newspapers or magazines. Slovene border sections with Austria recorded slightly lower percentages, in particular when it came to TV programmes (around $22 \%$ ). The percentages in question were even lower in the case of Slovene border sections with Hungary where the percentage of regular listeners and watchers varied between $7 \%$ and $11 \%$, whereas the customs in border sections with Croatia were similar to those in border sections with Italy.

\begin{tabular}{|l|c|c|c|c|}
\hline & I & A & H & CRO \\
\hline Radio & 7.5 & 6.7 & 7.2 & 12.3 \\
\hline TV & 40.6 & 21.7 & 11.0 & 30.3 \\
\hline Newspapers & 10.3 & 6.0 & 3.7 & 7.0 \\
\hline
\end{tabular}

Tab 5. Percentage of respondents who said to be regular audience of the media of the neighbouring country. Source: own research.

Another interesting aspect of the issue was to compare the results of the two surveys in regard to the frequency of cross-border visits, as it allowed us to examine whether the abolition of border posts indeed increased the intensity of functional cross-border ties. The table below confirms this hypothesis, revealing that all Slovene border areas, including the one with Croatia, witnessed a considerable increase in the frequency of visits to places on the other side of the border. The percentage of people who stated that they were a very frequent or, more precisely, regular (daily or at least weekly) visitors to neighbouring places in Italy increased from around $19 \%$ to around $36 \%$, the percentage of those visiting Austria from around $8 \%$ to around $12 \%$, the percentage of those visiting Hungary from around $4 \%$ to around $8 \%$, and 
the percentage of those visiting Croatia from around $5 \%$ to around $7 \%$. The frequency of crossborder visits thus witnessed the largest increased in the border area with Italy, where it had actually always been high, confirming the strong functional cross-border co-dependence of the area, the only one where very frequent cross-border visits were prevailing. The population of the border area with Austria increased the number of very frequent visits on the one hand, and decreased the number of periodic, monthly visits on the other, with the majority of them (56\%) visiting places on the other side of the border several times per year. Similar changes were recorded in the border areas with Hungary and Croatia, where up to two thirds of respondents claimed to pay visits to neighbouring places only once or a few times per year. The reason for such a change should most probably be sought in the fact that in the past few years both shopping offers and prices, which used to be the two major motivations for cross-border visits, became more equalized, whereas there was an increase in opportunities to work, study and, last but not least, live across the border, which were all activities calling for increased spatial mobility.

\begin{tabular}{|l|c|c|c|c|c|c|c|c|}
\hline & \multicolumn{2}{|c|}{} & \multicolumn{2}{c|}{$\mathrm{A}$} & \multicolumn{3}{c|}{$\mathrm{H}$} & \multicolumn{2}{c|}{ CRO } \\
\hline & 2007 & 2010 & 2007 & 2010 & 2007 & 2010 & 2007 & 2010 \\
\hline Every day & 7.2 & 9.4 & 0.4 & 3.2 & 0.0 & 1.2 & 1.6 & 1.6 \\
\hline At last once a week & 12.0 & 26.5 & 7.8 & 8.9 & 4.4. & 7.2 & 3.6 & 5.7 \\
\hline At last once a month & 33.5 & 32.9 & 32.8 & 25.1 & 28.1 & 17.8 & 20.2 & 16.6 \\
\hline At last once a year & 40.2 & 26.9 & 39.5 & 55.9 & 51.4 & 62.7 & 56.7 & 66.1 \\
\hline Never & 7.1 & 4.3 & 19.5 & 6.8 & 16.1 & 11.1 & 17.9 & 10.1 \\
\hline
\end{tabular}

Tab 6. Frequency of cross-border visits (in \%) in 2007 and 2010. Source: own research.

Such interpretation was corroborated by answers to the question about the motives for visiting neighbouring states, with shopping still being the main reason for cross-border visits in all border areas except the one with Croatia. Nevertheless, the percentage of respondents who went shopping across the border fell considerably: from around $48 \%$ to around $34 \%$ in the case of the Slovene-Italian border area, from around $48 \%$ to around $41 \%$ in the case of the border area with Austria, and from around $45 \%$ to around $41 \%$ in the case of the border area with Hungary. A reverse trend was observed only along the border with Croatia (the percentage of respondents in question increased from around $9 \%$ to around $14 \%$ ). In this border area, however, the most important motive for cross-border visits was tourism or recreation (trips, holidays, visits to restaurants), even though it slightly decreased in frequency. By contrast, in all other border areas the importance of this motive increased (from around 14\% to $23 \%$ along the border with Italy, from around $14 \%$ to as many as $28 \%$ along the border with Austria and from around $25 \%$ to $33 \%$ along the border with Hungary), which obviously corroborates the hypothesis that the abolition of border posts not only increased the number of cross-border trips, but also gave a spur to other basic activities in the fields of work, cultural events, etc.

What is also interesting is the fact that visits to relatives and friends recorded unchanged frequency in all border areas except that with Croatia where the percentage of respondents in question increased from around $16 \%$ to around $24 \%$, which testifies the gradual normalization of local cross-border social communication as a result of more relaxed relations between the two states, expecting Croatia to join the European Union in July 2013. The work motive acquired a greater importance also along the border with Austria, reaching the level characteristic of the border area with Italy, where as early as 2007 around $6 \%$ of the respondents stated that they themselves or one of their family members worked in the neighbouring country. A considerable increase was observed in the percentage of people attending cultural events along the border with both Italy and Croatia (from around $4 \%$ to around $14 \%$ and from around $2 \%$ to around $9 \%$ respectively), which shows that as a result of the "open border", cross-border cultural ties with the Slovene minority in Italy have been strengthened on the one hand, and that despite the erection of the EU's external border posts along the border with Croatia, transitional local social ties between the two countries have been re-established and maintained on the other.

One should also mention schooling, accounting for $2 \%$ of visits to neighbouring places in Italy and $1 \%$ to neighbouring places in other border areas. It is also interesting to note that along 
the border with Italy, more than $2 \%$ of respondents stated that their cross the neighbouring territory when commuting from the karst region and other parts of Western Slovenia to the Slovene coast since the route via Trieste was shorter both in terms of distance and time. Transit also accounted for $1 \%$ of responses along the border with Austria and Croatia. These two areas also witnessed cross-border visits (1\% in each case) resulting from the need to purchase medicines and the decision to participate in sporting activities, with the latter also being an important motive along the border with Hungary (accounting for around $2 \%$ of responses).

\begin{tabular}{|l|c|c|c|c|c|c|c|c|}
\hline & \multicolumn{2}{|c|}{} & \multicolumn{2}{c|}{ A } & \multicolumn{2}{c|}{ H } & \multicolumn{2}{c|}{ CRO } \\
\hline & 2007 & 2010 & 2007 & 2010 & 2007 & 2010 & 2007 & 2010 \\
\hline Work & 5.6 & 6.2 & 1.6 & 6.2 & 2.0 & 2.1 & 3.6 & 2.6 \\
\hline Shopping & 48.2 & 34.1 & 48.4 & 40.6 & 45.4 & 40.8 & 8.7 & 13.6 \\
\hline Visits to relatives / friends & 17.5 & 18.6 & 12.1 & 10.6 & 8.8 & 9.6 & 15.5 & 24.2 \\
\hline Trips / visit to restaurants & 14.3 & 23.0 & 13.7 & 27.9 & 24.9 & 33.0 & 48.4 & 43.7 \\
\hline Attending cultural events & 4.0 & 13.7 & 2.3 & 5.5 & 2.4 & 5.5 & 2.4 & 8.5 \\
\hline Other / no response & 10.4 & 4.4 & 21.9 & 9.2 & 16.5 & 9.0 & 21.4 & 7.4 \\
\hline
\end{tabular}

Tab 7. Motives for visiting neighbouring places (in \%) in 2007 and 2010.

In order to determine the level of cross-border cohesion, one should also take into account social distance indicators. The survey conducted in 2010 thus asked the population of Slovene border areas whether they would like that their neighbours would be people from neighbouring countries. It is negative answers that are most expressive of the level of social distance, which is, as it can be inferred from the table below, strongly dependent on geographical closeness, with the greater the closeness, the smaller the social distance. Such an observation corroborates the hypothesis that cross-border social communication and co-dependence increase the knowledge of one's neighbouring community, thus reducing potential conflicts and creating greater harmony between border communities. In addition, the survey of data reveals that respondents based the assessment of "less known" neighbours on certain stereotype images "ranking" them according to the perceived level of their "cultivation" and "congeniality".

Thus it is not surprising that in general respondents living in Slovene border areas fostered the smallest social distance to Austrians, whom an average of $13 \%$ of respondents would not want to be their neighbours, with this percentage being almost halved along the border with Austria and Hungary and almost doubled along the border with Italy. The border area with Italy fostered the smallest social distance to Italians with the result not differing considerably from the mean value (around $23 \%$ of respondents from all border areas would not want Italians to be their neighbours). In general, social distance to Hungarians and Croats recorded the highest and most similar values, with the average amounting to $26-27 \%$. In both cases, more favourable attitudes towards Hungarians and Croats were held by the population of the border areas with Hungary and Croatia respectively (in the case of the former, the percentage dropped to $13 \%$, in the case of the latter to $19 \%$ ).

\begin{tabular}{|l|c|c|c|c|}
\hline & I & A & H & CRO \\
\hline Italians & 18.1 & 27.8 & 20.4 & 26.5 \\
\hline Austrians & 21.9 & 6.1 & 8.0 & 15.1 \\
\hline Hungarians & 32.4 & 26.9 & 13.0 & 30.5 \\
\hline & 29.7 & 31.8 & 26.5 & 19.1 \\
\hline
\end{tabular}

Tab 8. Percentage of respondents from Slovene border areas who would not want their neighbours to be... Source: own research. 
Interesting answers were also obtained when respondents were asked whether in terms of their lifestyle and mentality people from Slovene border areas were more similar to people from areas on the other side of the border rather than to Slovenes living in the Slovene interior. The statement was supported by as many as $47-51 \%$ of respondents in the majority of Slovene border areas, with the exception of that with Croatia where only $36 \%$ of respondents agreed with it. Even higher support was expressed for the statement that people living in Slovene border areas assumed certain characteristics from their neighbours. As many as $66-71 \%$ of respondents from the majority of Slovene border areas agreed with it, with the percentage being considerably lower (around 51\%) along the border with Croatia.

\section{Conclusion: some comparative measures of social cross-border in Slovene border areas}

On the basis of our research into Slovene border areas, we conceived a set of synthetic indices for determining the level of cross-border cohesion (Bufon, 2008) by joining individual indicators into four basic groups: the first was related to the expectations of the border population as regards the future development of cross-border cohesion (e.g. the percentage of respondents believing that after Slovenia's admission to the EU and the Schengen Area cross-border ties would be strengthened); the second took into account potential factors of cross-border cohesion (e.g. the percentage of respondents who stated that they had friends or relatives living across the border); the third was related to the elements of social and cultural affinitieswith the neighbouring area (e.g. the percentage of respondents who stated that they understand/speak the neighbours' language or were regular audience of the cross-border media); and the fourth was related to the elements of cross-border functional co-dependence (e.g. the percentage of respondents who stated that they were regular visitors to neighbouring places owing to work or shopping). On the basis of these sections, we calculated the synthetic index expressing the mean value of previously calculated mean values of indicators related to individual groups.

\begin{tabular}{|l|c|c|c|c|}
\hline & I & A & H & CRO \\
\hline Index of "cross-border expectations" & 51.2 & 54.9 & 52.1 & 36.2 \\
\hline Index of potential cross-border cohesion & 62.3 & 52.9 & 58.5 & 55.7 \\
\hline Index of social and cultural affinities & 59.3 & 41.6 & 28.6 & 64.4 \\
\hline Index of functional cross-border co-dependence & 20.3 & 14.4 & 14.7 & 14.0 \\
\hline Synthetic mean index of cross-border cohesion & $\mathbf{4 8 . 3}$ & $\mathbf{4 1 . 0}$ & $\mathbf{3 8 . 5}$ & $\mathbf{4 2 . 6}$ \\
\hline
\end{tabular}

Tab 9. Synthetic overview of the level of cross-border cohesion in Slovene border areas (mean values of indicators). Source: own research.

The table reveals that the mean values of potential and functional cross-border cohesion "calculated" in such a manner were the highest in the border area with Italy, which also exhibits the highest total cross-border cohesion. Ranking second in terms of total cross-border cohesion is the border area with Croatia, which is mostly a result of a high level of social and cultural affinities. Ranking third is the Slovene-Austrian border area, where a relatively high level of expectations as regards the future development of cross-border ties compensates for a relatively low level of potential cross-border cohesion. The lowest total level of cross-border cohesion is exhibited by the border area with Hungary largely owing to a low level of social and cultural affinities with the neighbouring border area.

The analysis was also applied to individual sub-areas ( 3 along the border with Italy, 4 along the border with Austria, 2 along the border with Hungary and 4 along the border with Croatia) in order to gain a more precise ranking of the Slovene border sections according to total "degree" of cross-border cohesion. Distinctively above average values of cross-border cohesion were calculated for the sub-areas of Gorizia, Istria (along the border with Italy) and the easternmost part of Slovenia (along the border with Austria), while distinctively below average values were obtained for the Gorenjska region (the westernmost part of Slovenia bordering Austria), as well 
as the northern part of Slovenia bordering Hungary, where less favourable geographical conditions were an additional factor impeding the development of cross-border ties and communication.

The survey presented in this article shows that the direction, intensity and type of cross-border ties can be not only appropriately studied and qualitatively and quantitatively assessed, but also compared both in terms of time (diachronic approach) and space (synchronic approach). The research into this phenomenon should be focused on different forms of cross-border cooperation, as well as the impacts of the abolition of political borders and liberalization of border regimes upon social and spatial ties. The subject gives rise to the question of how to plan and implement such institutional, administrative and functional regimes that would enable the border population and the border area to successfully deal with its development dilemmas in the light of increasing social and spatial (re)integration of border areas and their development into a cross-border region. What is of vital importance to such engagement is not only a more carefully planned government policy on border areas but also the decentralization and (above all cross-border) regionalization of local structures of government. Unfortunately, such an approach to social and spatial planning in strongly co-dependent border areas has not been undertaken yet in Slovenia and its neighbouring environments. Naturally, joint policies should also be based on ample research experience and significant achievements of international and Slovene science in studies related to border issues, social contact and impacts of simultaneous evolution of convergent and divergent processes in Slovene contact areas.

\section{Acknowledgement}

The publishing of the paper is supported by the Visegrad Fund, project Nr. 11220149 "Borders and Borderlands within the Central Europe".

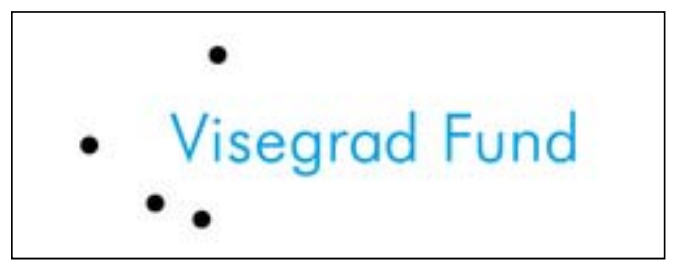

References

[1] Bufon, M. (1993). Elementi obmejnosti in faktorji oblikovanja prekomejnih območij na primeru Slovenije. Dela 10, 99-109.

[2] Bufon, M. (1995). Prostor, meje, ljudje - razvoj prekomejnih odnosov, struktura obmejnega območja in vrednotenje obmejnosti na Goriškem. Trieste, Slori.

[3] Bufon, M. (1996). Naravne, kulturne in družbene meje. Annales 8, 177-186.

[4] Bufon, M. (1998). Le regioni transfrontaliere nel processo di unificazione europea. In: Bonavero, P. \& Dansero, E., eds., L'Europa delle regioni e delle reti (pp. 126-142). Torino, Utet.

[5] Bufon, M. (2001a): Geografija obmejnosti, čezmejne regije in oblike čezmejne povezanosti. Geografski vestnik 73(2), 9-24.

[6] Bufon, M. (2001b). Oblikovanje čezmejnih vezi na tromeji med Slovenijo, Hrvaško in Italijo v Istri. Dela 16, 39-60.

[7] Bufon, M. (2002). Slovenia - a European contact and border area. Annales 11(2), 445-472.

[8] Bufon, M. (2006a): Geography of border landscapes, borderlands and Euroregions in the enlarged EU. Rivista geografica italiana 113(1), 47-72. 
[9] Bufon, M. (2006b). Between social and spatial convergence and divergence an exploration into the political geography of European contact areas. GeoJournal 66(4), 341-352. Doi: 10.1007/s10708-006-9008-1.

[10] Bufon, M. (2008). Na obrobju ali v osredju? Slovenska obmejna območja pred izzivi evropskega povezovanja. Koper: Založba Annales.

[11] Bufon, M. (2010). Geografija in medkulturnost. In Sedmak, M. \& Ženko, E., eds., Razprave o medkulturnosti (pp. 89-112). Koper: Univerzitetna založba Annales.

[12] Bufon, M. (2011). „Ne vrag, le sosed bo mejak!« Upravljanje integracijskih procesov v obmejnih območjih. Koper: Univerzitetna založba Annales.

[13] House, J. W. (1981). Frontier studies - an applied approach. In Burnett, A. D. \& Taylor, P. J., eds., Political Studies from Spatial Perspectives (pp. 291-312). New York, Wiley.

[14] Maier, J., Paesler, R., Ruppert, K. \& Schaffer, F. (1977). Sozialgeographie. Braunschweig: Georg Westermann Verlag.

[15] Paasi, A. (2009). Bounded spaces in a 'borderless world: border studies, power and the anatomy of territory. Journal of Power 2(2), 213-234. Doi: 10.1080/17540290903064275.

[16] Prescott, J. R. V. (1987). Political Frontiers and Boundaries. London: Allen \& Unwin.

[17] Reynolds, D. R. \& McNulty, M. L. (1971). On the analysis of political boundaries as barriers - a perceptual approach. East Lake Geographer 23, 21-38.

[18] Rumley, D. \& Minghi, J. V. (1991). The Geography of Border Landscapes. London: Routledge.

[19] Segall, M. H. et al. (1966). The Influence of Culture on Visual Perception. Indianapolis: Bobbs-Meriell.

[20] Sonnenfeld, J. (1976). Geography, perception, and the behavioral environment. In English, J. \& Mayfield, S., eds., Man, Space, and Environment (pp. 244-251). New York: Wiley.

[21] Strassoldo, R., ed. (1973). Confini e regioni. Trieste: Lint. 